\begin{tabular}{|c|c|c|c|c|c|c|}
\hline \multirow{4}{*}{ Impact Factor: } & ISRA (India) & $=3.117$ & SIS (USA) & $=0.912$ & ICV (Poland) & $=6.630$ \\
\hline & ISI (Dubai, UAE & $=0.829$ & РИНЦ (Russia) & $=0.156$ & PIF (India) & $=1.940$ \\
\hline & GIF (Australia) & $=0.564$ & ESJI (KZ) & $=8.716$ & IBI (India) & $=4.260$ \\
\hline & JIF & $=1.500$ & SJIF (Morocco) & $=5.667$ & OAJI (USA) & $=0.350$ \\
\hline
\end{tabular}

\begin{tabular}{|c|c|}
\hline $\begin{array}{l}\text { SOI: } \frac{1.1 / \mathrm{TA}}{} \\
\text { International Sc } \\
\text { Theoretical } \mathbb{\&} \mathbf{A}\end{array}$ & $\begin{array}{l}\frac{S}{\text { DOI: }} 10.15863 / \mathrm{TAS} \\
\text { ientific Journal } \\
\text { pplied Science }\end{array}$ \\
\hline p-ISSN: 2308-4944 (print) & e-ISSN: 2409-0085 (online) \\
\hline Year: 2019 Issue: 05 & Volume: 73 \\
\hline Published: 16.05 .2019 & http://T-Science.org \\
\hline
\end{tabular}

UDC: 595.598 .132
QR - Issue

QR - Article
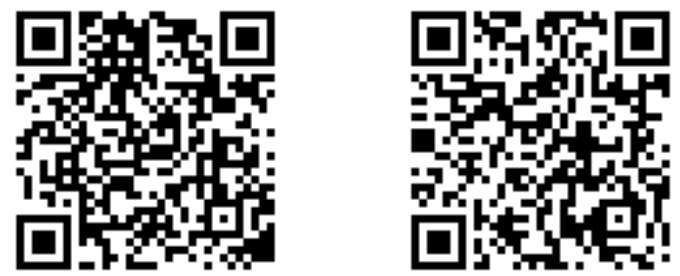

Kalandar Abdullaevich Saparov Doctor of Biological Sciences, Professor,

Dean of the Faculty of Natural Sciences Tashkent state pedagogical university named after Nizami, Uzbekistan ka_bioligiya@mail.ru

Said Dadaevich Dadaev

Doctor of Biological Sciences, Professor of the Department of Zoology and Anatomy Tashkent state pedagogical university named after Nizami, Uzbekistan s_dadaev@mail.ru

Ziyoda Mirsaid Kizi Mirkomilova third year student "Methods of teaching biology" Tashkent state pedagogical university named after Nizami, Uzbekistan

\title{
STRUCTURAL CHARACTERISTICS OF THE FILARIAT FAUNA OF WARM-BLOODED ANIMALS OF UZBEKISTAN
}

Abstract: Some features of the fauna and distribution of the nematodes of the suborder of the parasite filarial parasites of warm-blooded animals of Uzbekistan have been studied. A total of 76 species of filariats were recorded; 53 species were recorded in various ecological groups of birds and 23 mammals. Of the total number of species, 48 are observed in Uzbekistan for the first time. The original data on the qualitative composition and structure of communities of filariat-endoparasites of warm-blooded animals are given.

Key words: nematodes, filariates, fauna, birds, mammals, warm-blooded.

Language: English

Citation: Saparov, K. A., Dadaev, S. D., \& Mirkomilova, Z. M. (2019). Structural characteristics of the filariat fauna of warm-blooded animals of Uzbekistan. ISJ Theoretical \& Applied Science, 05 (73), 71-76.

Soi: http://s-o-i.org/1.1/TAS-05-73-14 Doi: crossef https://dx.doi.org/10.15863/TAS.2019.05.73.14

\section{Introduction}

Filariata form a large and widely distributed group of parasitic nematodes that cause a series of very dangerous diseases in humans and animals, which are called "filariases". "According to the World Health Organisation (WHO), about 120 million people around the world living in the subtropical and tropical zones are infected with filariases, with about 40 million being disabled persons, whose disability was caused by lymphatic filariases and lymphatic tumours" [5].

Filariata cause a number of parasitic diseases in wild and domestic animals, such as parafilariasis, onchocercosis, setariosis, stephanofilariasis and dipetalonemosis, and thus cause huge economic damage to cattle breeding and processing industries.
The development of effective measures for the prevention of helminthiasis, including filariasis of warm-blooded animals and humans, largely depends on the completeness of our knowledge of the fauna and life cycles of the causative agents of these diseases.

Moreover, this group of parasites has long been less studied in the biogeocenoses of Uzbekistan. The available information (Sultanov, 1963; Golovanov, 1973; Sultanov et al., 1975; Dadaev, 1978, 1997; Kabilov, 1983; Saparov, 2006, etc.) is fragmentary and these data are rather outdated.

Proceeding from this, the study of the fauna and the distribution of the filariat of warm-blooded animals in various conditions of Uzbekistan has a great theoretical and practical importance. 


\begin{tabular}{|c|c|c|c|c|c|c|}
\hline \multirow{4}{*}{ Impact Factor: } & ISRA (India) & $=3.117$ & SIS (USA) & $=0.912$ & ICV (Poland) & $=6.630$ \\
\hline & ISI (Dubai, UAE & $=0.829$ & РИНЦ (Russia & $=0.156$ & PIF (India) & $=1.940$ \\
\hline & GIF (Australia) & $=0.564$ & ESJI (KZ) & $=8.716$ & IBI (India) & $=4.260$ \\
\hline & JIF & $=1.500$ & SJIF (Morocce & $=5.667$ & OAJI (USA) & $=0.350$ \\
\hline
\end{tabular}

The goal of this research is to analyze the results of our many years of research and literature data on the fauna and distribution of filariat- nematodes of warm-blooded animals in various biocenoses of Uzbekistan.

\section{Material and methods}

As a basis of this work we used from the materials of field and experimental researches, conducted during 2000-2018 years in the laboratory of parasitology of the Institute of Zoology of Academy of Sciences of Uzbekistan, and at the department of Zoology and Anatomy of the Tashkent State Pedagogical University named after Nizami.

The main material was the qualitative and quantitative collections of filariats collected from warm-blooded animals (birds and mammals), inhabitants of aquatic and terrestrial cenoses in five regions of Uzbekistan. Wild animals were got during the hunting season, and domestic animals were investigated at slaughter points and meat-processing combines in all regions of the republic. The degree of infection of warm-blooded animals with filariats was established by complete and incomplete helminthological autopsy birds and mammals, as well as their individual organs according to the method of K.I. Scriabin (1928). More than 3750 birds and 1550 mammals were studied. Also, biopsies were examined that were infected with domestic animal filarias (cattle, horses) -350 samples by known methods (Gnedina, 1940; Ivashkin, 1969).

The detected nematodes were studied by known methods of parasitology (Petrov, 1963; Sonin, 1966, 1968, 1975; Anderson, 2000).

The shown warm-blooded animals were investigated in all seasons of the year from various landscapes. Also, fallen birds and other animal species from the Tashkent Zoo were investigated, presented to us to establish of infection by parasites.

The detected nematodes, considered of suborder were fixed in Barbagallo fluid, and in some cases in $70 \%$ alcohol. Under processing of the species of filariat, it was used in equally level of lactic acid and glycerin. The species definition of the filariat was carried out by the known methods of parasitology.

\section{Results and discussion}

We found that the nematodes of the suborder Filariata in warm-blooded animals of Uzbekistan were represented by 76 species. Of these, 53 species were recorded in birds and 23 ones in mammals.

As noted above, 53 species of filarias belonging to 22 genera and 4 families were recorded in various ecological groups of birds (Table 1).

Table 1. The structure of the fauna of bird filariat-nematodes of Uzbekistan

\begin{tabular}{|l|c|c|}
\hline \multirow{2}{*}{\multicolumn{1}{|c|}{ Family }} & \multicolumn{2}{c|}{ Quantity } \\
\cline { 2 - 3 } & genus & species \\
\hline Aproctidae & 4 & 9 \\
\hline Splendidofilariidae & 6 & 12 \\
\hline Diplotriaenidae & 5 & 20 \\
\hline Lemdanidae & 7 & 12 \\
\hline Total & 22 & 53 \\
\hline
\end{tabular}

Aproctidae are represented by 9 species from the genera Aprocta (6), Aproctoides (1), Squamofilaria (1) and Pseudoprocta (1). Representatives of Splendofilariidae belong to 12 species from six genera (Splendidofilaria- 4, Sarconema - 2, Skrjabinocta - 1, Ornithofilaria - 3, Vagrifilaria - 1 and Parornithofilaria - 1). Nematodes of the family Diplotriaenidae consist of 20 species belonging to 5 genera (Diplotriaena - 13, Dicheilonema - 1,
Hamatospiculum - 1, Petrovifilaria - 1 and Serratospiculum - 3). Filariae from the family of Lemdanidae are represented in our material by 12 species from six genera (Lemdana - 1, Eulemdana - 1, Cardiofilaria - 1, Dirofilarionema - 1, Pseudalemdana - 1, Pelecitus - 2 and Paronchocerca - 5). The portion of birds infected with filariae was $13.8 \%$. The portion of birds with filariae in each of the group ranged from 2.0 to $31.6 \%$ (Fig. 1). 


\begin{tabular}{llllll} 
& ISRA (India) $=\mathbf{3 . 1 1 7}$ & SIS (USA) $=\mathbf{0 . 9 1 2}$ & ICV (Poland) & $=\mathbf{6 . 6 3 0}$ \\
Impact Factor: & ISI (Dubai, UAE) $=\mathbf{0 . 8 2 9}$ & PUHЦ (Russia) $=\mathbf{0 . 1 5 6}$ & PIF (India) & $=\mathbf{1 . 9 4 0}$ \\
& GIF (Australia) $=\mathbf{0 . 5 6 4}$ & ESJI (KZ) & $=\mathbf{8 . 7 1 6}$ & IBI (India) & $=\mathbf{4 . 2 6 0}$ \\
& JIF & $\mathbf{1 . 5 0 0}$ & SJIF (Morocco) $=\mathbf{5 . 6 6 7}$ & OAJI (USA) & $\mathbf{0 . 3 5 0}$ \\
\hline
\end{tabular}

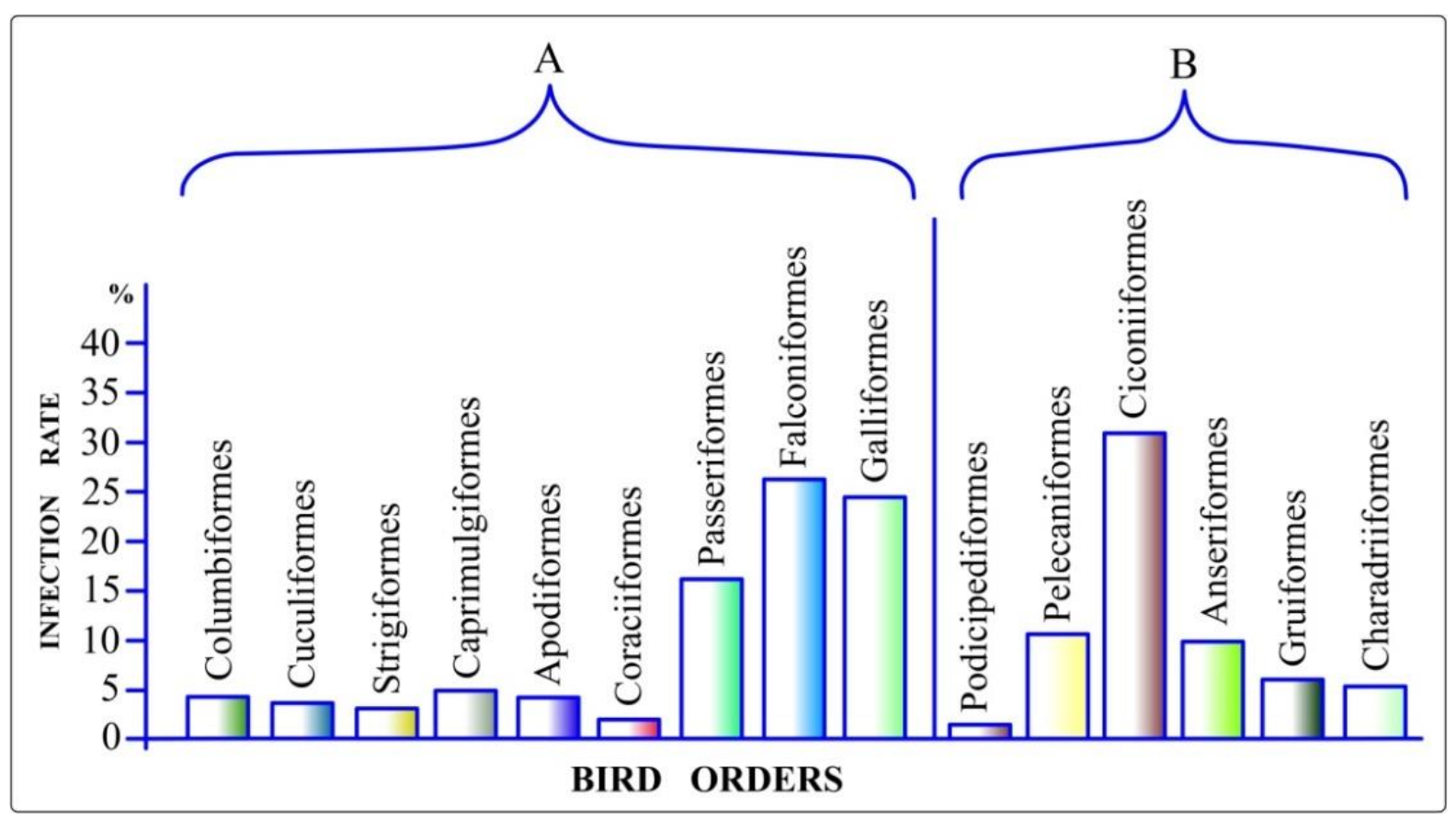

Fig. 1. The rate of infection with Filariata among birds: A - terrestrial birds, B - aquatic and semi-aquatic birds (original).

Adult Filariata parasitising the birds of Uzbekistan can be divided into two groups by their ecological characteristics. The first ecological group includes species parasitising terrestrial birds (Falconiformes, Galliformes, Columbiformes, Cuculiformes, Strigiformes, Caprimulgiformes, Coraciiformes and some species of Gruiformes, Apodiformes, Passeriformes). The second ecological group consists of filaria species parasitising aquatic and semi-aquatic birds (Pelecaniformes, Ciconiiformes, Anseriformes, Gruiformes, Charadriiformes).

The filariats we have mentioned include species with a small range of hosts, them being oligoxenic forms and species parasitising in many species of birds from different orders. The examples of oligoxenic groups include Aprocta caprimugli, which was found only in the Caprimulgiformes, two types of specific parasites of the Falconiformes Serratospiculum tendo, S. chungi, and Petrovifilaria mongolica parasitising the Gruiformes, mainly the Bustard. Most of the species from different filaria genera parasitising birds from various orders may serve as examples of euryxenic groups.

The results of the research demonstrated that a significant number of mammal species were infected with nematodes of the suborder Filariata.

The mammals of Uzbekistan were recorded to be the hosts of 23 species from 9 genera - Onchocerca, Dipetalonema, Dirofilaria, Litomosa, Parafilaria, Skrjabinodera, Micipsella, Setaria, Stephanofilaria and 5 families - Filariidae, Dipetalonemidae, Onchocercidae, Setariidae, Stephanofilariidae (Table 2).

Table 2. The structure of the fauna of the mammalian filariat nematode of Uzbekistan

\begin{tabular}{|l|c|c|}
\hline \multirow{2}{*}{ Family } & \multicolumn{2}{c|}{ Quantity } \\
\cline { 2 - 3 } & genus & species \\
\hline Filariidae & 2 & 5 \\
\hline Onchocercidae & 4 & 9 \\
\hline Setariidae & 1 & 2 \\
\hline Diplotriaenidae & 1 & 2 \\
\hline Splendidofilariidae & 1 & 23 \\
\hline Total & 9 & \\
\hline
\end{tabular}

A high infection rate was observed in Perissodactyla (33.3\%) and Artiodactyla (40.3\%).

The parasitizing filariasis among representatives in 7 orders of mammals represented by Fig. 2 .
The average rate of infection among the mammals of Uzbekistan is $25.07 \%$. The infection rate varies greatly depending on the group of mammals. 


\begin{tabular}{|c|c|c|c|c|c|c|}
\hline \multirow{4}{*}{ Impact Factor: } & ISRA (India) & $=3.117$ & SIS (USA) & $=0.912$ & ICV (Poland) & $=6.630$ \\
\hline & ISI (Dubai, UAI & $=0.829$ & РИНЦ (Russia & $=0.156$ & PIF (India) & $=1.940$ \\
\hline & GIF (Australia) & $=0.564$ & ESJI (KZ) & $=8.716$ & IBI (India) & $=4.260$ \\
\hline & JIF & $=1.500$ & SJIF (Morocco & $=5.667$ & OAJI (USA) & $=0.350$ \\
\hline
\end{tabular}

The lowest rate was observed in representatives of Rodentia (9.8\%) and Chiroptera (14.0\%).

Characterising the Filariata we should, first of all, note the diversity of places in a mammal organism where they tend to live. At the same time, we should note that no adult filariae of any species live in the digestive tract of mammals, which is a usual place for most of the nematodes from other suborders. All Filariata species have adapted to living in the organs of closed systems, having abandoned the digestive tract of the vertebrate host long ago.

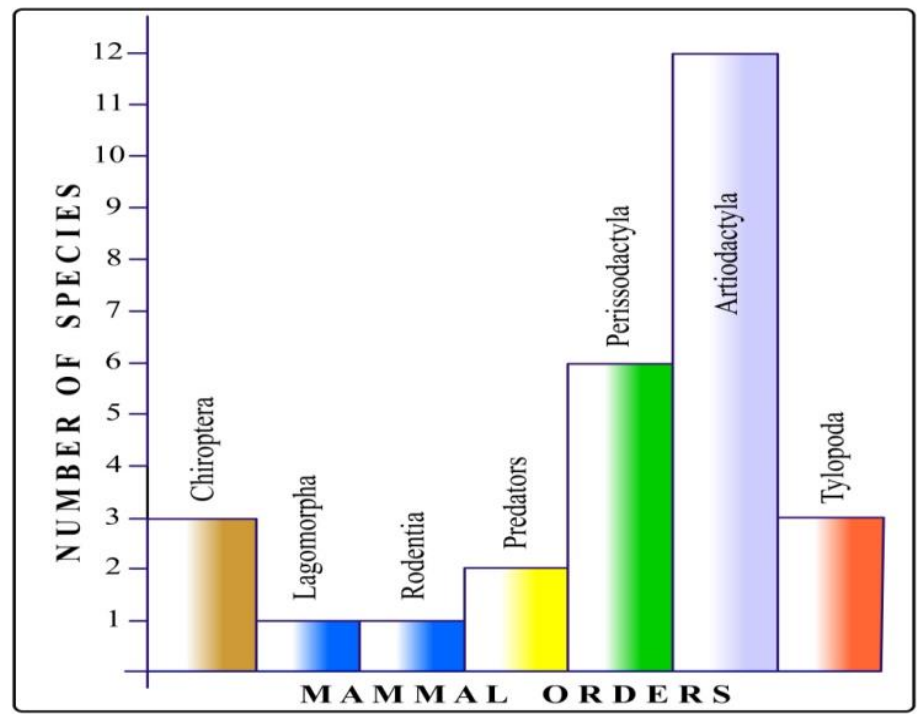

Fig. 2.The structure of the filaria fauna of certain groups of mammals (original).

Filariates are spread in mammals, on all continents of the globe (Sonin, 1975, 1977; Anderson, 2000). In this regard, it can be assumed that the species diversity of mammalian filariats in Uzbekistan and adjacent territories practically corresponds to those of other large regions. In the qualitative ratio, the species composition of the filariat of the studied regions of Uzbekistan also differs little from the fauna of these nematodes of mammals of other zones, at least within the Palearctic. This is indicated by the fact that most of the species we registered, the species were distributed throughout the Eurasian continent.

In conclusion we can note, that one of the main directions of development of parasitology at the present time is the synthesis of factual materials and the preparation of works summarizing the studies of the species diversity of certain taxonomic groups of vertebrate helminthes of a certain region of the country. Such works are of great interest because they serve as the basis for further research and the development of methods for the prevention of parasitic diseases of economically important groups of animals. In this context, this article was implemented. It is dedicated to the comprehensive study of the peculiar groups of nematodes of the suborder Filariata Skrjabin, 1915 species of parasites of warm-blooded animals of Uzbekistan. Analysis and synthesis of research results indicate that the filariats of warmblooded animals of the fauna of Uzbekistan are not sufficiently studied in terms of ecology and fauna directions (Sultanov, 1963; Sultanov et al., 1975). We have established the species composition of the filariat of separate ecological groups of warm-blooded animals studied in different seasons of the year. Some pecularities of the regional distribution of the studied parasites of these hosts, animals, are considered.

It should be noted that infection of warmblooded animals with filarias of individual taxonomic groups occurs through separate cenotic channels, which indicates the importance of cenotic connections of the hosts in the formation of their fauna of the filariat.

The complex of species constituting the fauna of the filarias of the studied groups of animals is heterogeneous in the sense of their morphological properties and biocenotic relationships with the hosts, which were probably formed during a long historical period during the evolution of the system of the type of bird filaria-bird and filarial-mammalian. In the biogeocenoses of Uzbekistan, warm-blooded animals have 76 species of filarial. Most of the species of the filariat is ecologically related only to birds, more precisely, their individual groups. The species diversity of mammalian filariats was 23 . At the same time, it should be noted that the specificity of the filariat in the imago phase is quite clearly expressed in relation to the host. They are characterized by the presence of group specificity, which is expressed in the association of individual families of nematodes to large taxonomic groups of vertebrate hosts (classes, orders). This is clearly manifested in the filarial known families (Aproctidae, Splendidofilariidae, 


\begin{tabular}{|c|c|c|c|c|c|c|}
\hline \multirow{4}{*}{ Impact Factor: } & ISRA (India) & $=3.117$ & SIS (USA) & $=0.912$ & ICV (Poland) & $=6.630$ \\
\hline & ISI (Dubai, UAE & $=0.829$ & РИНЦ (Russia & $=0.156$ & PIF (India) & $=1.940$ \\
\hline & GIF (Australia) & $=0.564$ & ESJI (KZ) & $=8.716$ & IBI (India) & $=4.260$ \\
\hline & JIF & $=1.500$ & SJIF (Morocce & $=5.667$ & OAJI (USA) & $=0.350$ \\
\hline
\end{tabular}

Diplotriaenidae, Lemdanidae), which include only parasites of birds; representatives-Filariidae, Setariidae, Onchocercidae, Dipetalonemidae and Stephanofilariidae-mammals. It is well known that to establish kinship over species, the specificity of parasites to their hosts is of great importance as one of the serious taxonomic features. The validity of this provision and in relation to a peculiar group, considered nematodes, is undoubted.

The diversity of the fauna of the filariat and the considerable specialization of many families of its genera quite convincingly indicate that the formation of the faunal complexes, like other parasites, took place under the control of a multitude of environmental factors. The implementation of biocenotic relations between the parasite and the host in time and space contributed to the formation of the fauna of the studied animals' filarias and the emergence of parasitic relationships.

\section{Conclusions}

1. On the territory of Uzbekistan, 76 species of filariats are registered in warm-blooded animals. Of the total number of species, 53 were noted in birds, 23 were in mammals, uniting in 28 genera and 9 families. 48 species of filariats for the first time are noted for the fauna of Uzbekistan and one species is Parancho cercabumpae Anderson et Prestwood, 1969 for the fauna of Palearctic. As a new owner of this species, we have established the African marabou (Leptoptilo scrumeniferus) from the Tashkent zoo. The number of noted species of filarial animals of Uzbekistan makes up more than $13.0 \%$ of the world fauna of the suborder under consideration.

2. Localization of outside digestive tract is typical for filarias. Characterizing the considered nematodes from this side, it should be noted a variety of places of their parasitism in the organism of vertebrate - hosts. Most species of filarial animals of warm-blooded animals have adapted to localization in organs that are not communicating with the external environment. And in this regard, filariats also differ from other sub-divisions of nematodes.

3. The diversity of the fauna of the filariate and the specialization of many families of its genera suggests that the formation of faunal complexes, like other parasites, took place under the control of many environmental factors. The implementation of biocenotic relations between the parasite and the host in time and space contributed to the emergence of parasitic relations of the type of filaria-warm-blooded animals.

\section{References:}

1. Gnedina, M. P. (1940). Izuchenie etiologii i prizhiznennoy diagnostiki gel'mintoznykh porazheniy kozhi krupnogo rogatogo skota. Vestn. s.-kh. nauki, ser. Vet., T. 1. N 4. pp.89103.

2. Golovanov, V. I. (1973). Biologiya Onchocerca gutturoza Neumann, 1910 i epizootologiya onkhotserkozov krupnogo rogatogo skota $v$ Uzbekistane: Abstract of the candidate's thesis science biologies. (p.33). Dushanbe.

3. Dadayev, S. D. (1978). Ekologo-geograficheskie osobennosti gel'mintov domashnikh kopytnykh zhivotnykh yuga Uzbekistana. Abstract of the candidate's thesis. (p.24). Moscow.

4. Dadayev, S. D. (1997). Gel'minty pozvonochnykh podotryada Ruminantia Scopoli, 1777 fauny Uzbekistana. Abstract of the doctoral thesis. (p.56). Toshkent.

5. (2016). Informatsionnyy byulleten' Vsemirnoy organizatsii zdravookhraneniya, №387. http://www.who.int/mediacentre/factsheets/fs38 7/ru/index6.html
6. Ivashkin, V. M. (1969). Stefanofilyariozy kozhi vnutrennikh poverkhnostey ushnykh rakovin krupnogo rogatogo skota. Probl. parazitol. Kiev: «Naukova dumka», №2, pp.23-24.

7. Kabilov, T. K. (1983). Gel'minty pozvonochnykh zhivotnykh Uzbekistana, razvivayushchiesya s uchastiem nasekomykh. (p.128). Toshkent: «Science» Uzb. ASR.

8. Petrov, A. M. (1963). Gel'mintologicheskie issledovaniya. In book Veterinary laboratory practice. (pp.211-240). Moscow.

9. Saparov, K. A. (2006). Ekologo-biologicheskie osobennosti gel'mintov verblyudov-Camelus Linnatus, $1758 \mathrm{v}$ usloviyakh Uzbekistana. Abstract of the candidate's thesis science biologies. (p.24). Toshkent.

10. Skryabin, K. I. (1928). Metody polnykh gel'mintologicheskikh vskrytiy pozvonochnykh, vklyuchaya cheloveka. (p.45). Moscow, L.: Izd. MGU.

11. Sonin, M. D. (1966). Bases nematodologies. Filyariaty zhivotnykh i cheloveka i vyzyvaemye 


\begin{tabular}{|c|c|c|c|c|c|c|}
\hline \multirow{4}{*}{ Impact Factor: } & ISRA (India) & $=3.117$ & SIS (USA) & $=0.912$ & ICV (Poland) & $=6.630$ \\
\hline & ISI (Dubai, UAE & $=0.829$ & РИНЦ (Russia & $=0.156$ & PIF (India) & $=1.940$ \\
\hline & GIF (Australia) & $=0.564$ & ESJI (KZ) & $=8.716$ & IBI (India) & $=4.260$ \\
\hline & JIF & $=1.500$ & SJIF (Morocce & $=5.667$ & OAJI (USA) & $=0.350$ \\
\hline
\end{tabular}

imi zabolevaniya. Aproktoidei. Moscow: Science T.17. N.1. p. 360.

12. Sonin, M. D. (1968). Bases nematologies. Filyariaty zhivotnykh $i$ cheloveka $i$ vyzyvaemye imi zabolevaniya. Moscow: Science, T. 21. N. 2. p. 389.

13. Sonin, M. D. (1975). Bases nematologies. Filyariaty zhivotnykh i cheloveka i vyzyvaemye imi zabolevaniya. Filariats, onchosertses. Moscow: Science, T. 24. N. 3. p.395.

14. Sonin, M. D. (1977). Bases nematodologies. Filyariaty zhivotnykh $i$ cheloveka $i$ vyzyvaemye imi zabolevaniya. Moscow: Science, T.28. p.22.
15. Sultanov, M. A. (1963). Gel'minty ptits Uzbekistana. (p.468). Toshkent: Science.

16. Sultanov, M. A., Azimov, D. A., Gextin, V. I., \& Muminov, P. A. (1975). Gel'minty domashnikh mlekopitayushchikh Uzbekistana. (p.188). Toshkent: Science.

17. Anderson, R. K. (2000). Nematode parasites of vertebrates: their development and transmission. (p.650). New York: CAB International. 